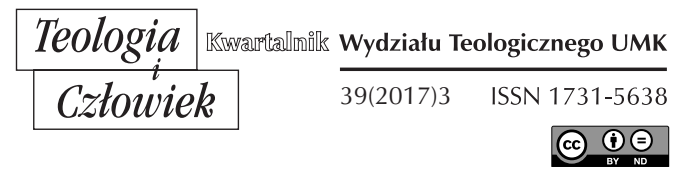

KS. SŁAWOMIR TYKARSKI*

TORUŃ

\title{
KONCEPCJA DOJRZAŁEJ OSOBOWOŚCI ORAZ JEJ WYZNACZNIKI - PROLOG DO ROZWAŻAŃ W KONTEKŚCIE OSÓB PRZYGOTOWUJĄCYCH SIĘ DO MAŁŻEŃSTWA
}

DOI: http://dx.doi.org/10.12775/TiCz.2017.036

Przyglądając się aktom spraw o stwierdzenie nieważności małżeństwa Sądu Biskupiego Diecezji Toruńskiej, można zauważyć, że najczęściej podawaną przyczyną jest kanon 1095 3ํ․ który brzmi: „Niezdolni do zawarcia małżeństwa są ci, którzy z przyczyn natury psychicznej nie są zdolni podjąć istotnych obowiązków małżeńskich"1. Zakres znaczeniowy tego sformułowania zawiera również przypadki, gdzie małżonkom brak

* Ks. dr Sławomir Tykarski jest adiunktem w Katedrze Teologii Praktycznej Wydziału Teologicznego UMK (tykarek@gmail.com).

${ }^{1} \mathrm{Na}$ podstawie analizy dokumentów sądowych w latach 2005-2010.

„Prawo kanoniczne nie wymaga od kandydatów do małżeństwa expressis verbis dojrzałej osobowości, lecz stawia im inne szczegółowe wymagania, które sprowadzają się do wymagania dojrzałości lub są mu podobne". Niemniej w obszarze znaczeniowym kanonu 1095 nr 3 mieści się „wielka niedojrzałość osobowościowa oraz skrajny egoizm”. R. Sztychmiler, Przygotowanie do małżeństwa w aspekcie osobowości kandydata, w: Osobowość kandydata do małżeństwa, R. Sztychmiler (red.), Olsztyn 1999, s. 85, 87. 
dojrzałej osobowości, czyli zdolności psychologicznej, która stawała się przeszkodą w utrzymywaniu związku. Małżonek nie był w stanie budować emocjonalnej więzi z partnerem, podejmować ról i funkcji wypływających z poszczególnych faz życia małżeńskiego ${ }^{2}$, odseparować się od rodziny pochodzenia, zaznaczając swoją odrębność i wolność, wytrwale stawiać czoła trudom, konfliktom i kryzysom związanym z życiem małżeńskim zamiast uciekać od odpowiedzialności i podejmowania wysiłków ${ }^{3}$. Obserwując niektóre małżeństwa, można zauważyć tendencję związaną z brakiem dojrzałej osobowości, która staje się przyczyną rozpadu związków. Statystyki rozwodzących się małżeństw świadczą o problemie polegającym na braku dyspozycji do utrzymania małżeństwa i walki o jego trwałość ${ }^{\text {. }}$

Niniejsze opracowanie jest teoretycznym szkicem przedstawiającym koncepcje dojrzałej osobowości i podającym jej wyznaczniki. Stanowi to wstęp do dalszych rozważań ukazujących przełożenie, jakie na małżeńskie relacje ma brak posiadania dojrzałej osobowości.

\section{OKREŚLENIE I DEFINICJA OSOBOWOŚCI}

Niewątpliwie określenie tego, czym jest osobowość nastręcza niemałych trudności, bowiem trudno pogodzić ze sobą to, co jest wspólne wszystkim ludziom przy jednoczesnym zróżnicowaniu indywidualnym oraz jednostkowej niepowtarzalności ${ }^{5}$. Ponadto ujęcie i charakterystyka osobowości zależeć będzie od podejścia psychologicznego, teoretycznych przekonań czy posiadanej filozofii. Inaczej bowiem będzie ją charakteryzował Sigmund Freud a w innym sposób Burrhus F. Skinner ${ }^{6}$. „W efekcie,

2 Odnośnie do poszczególnych faz życia małżeńsko-rodzinnego i ich specyfiki zob. I. Namysłowska, Terapia rodzin, Warszawa 1997, s. 18-23.

3 Zob. D. Dobkowska, Zdolność psychologiczna do matżeństwa, w: Osobowość kandydata do małżeństwa, R. Sztychmiler (red.), Olsztyn 1999, s. 75.

${ }^{4}$ Dla przykładu w roku 1990 zawarto 255369 małżeństw zaś rozwiodło się 42436. W 2015 roku rozwiodło się 67296 na 188832 zawartych małżeństw. Zob. Główny Urząd Statystyczny, Rocznik Demograficzny, Warszawa 2016, s. 187.

${ }^{5}$ Zob. D. Cervone, L.A. Pervin, Osobowość. Teoria i badania, Wyd. 10, Kraków 2011, s. 9.

${ }^{6}$ Freud był przekonany, że zachowanie człowieka jest kontrolowane przez siły wewnętrzne, które wypływają z podświadomości człowieka, natomiast Skinner uważał, 
można analizować osobowość z pespektywy psychoanalizy, behawioryzmu, psychologii humanistycznej, psychologii poznawczej" ". Stąd trzeba przyjąć definicję, z której treścią będzie zgodna większość psychologów osobowości. W związku z tym na potrzeby niniejszego artykułu osobowość należy rozumieć jako „cechy psychologiczne, które przyczyniają się do względnie trwałych i wyróżniających daną jednostkę wzorów odczuwania, myślenia i zachowania”. Mówiąc „względnie trwałych” ma się na myśli dość stałe właściwości, którymi charakteryzuje się jednostka niezależnie od miejsca, czasu i sytuacji. Tak więc struktura osobowości odnosi się do względnie trwałych jej aspektów9. Użyte zaś sformułowanie „przyczyniają się” odnosi się do czynników psychologicznych, które stają się przyczynami wywierającymi określony wpływ, czyli w jakiejś mierze wyjaśniają właściwe poszczególnym jednostkom wyróżniające i względnie trwałe tendencje. Natomiast terminy „odczuwanie, myślenie i zachowanie” określają nic innego, jak wszystkie aspekty osoby, czyli jej życie umysłowe, emocjonalne i zachowanie.

\section{CECHOWE UJĘCIE OSOBOWOŚCl}

Jak zostało wyżej wspomniane, koncepcje osobowości zależą od podejścia psychologicznego. W niniejszym opracowaniu nie jest możliwe wymienienie i scharakteryzowanie wszystkich, dlatego zostanie zaprezentowane tylko ujęcie humanistyczne, którego reprezentantami są między innymi Gordon W. Allport i Raymond B. Cattell ${ }^{10}$. Ci dwaj

iż priorytetowe znaczenie mają czynniki środowiskowe czyli oddziaływanie świata na jednostkę. Są to dwa różnie skrajne podejścia. Współcześni psychologowie osobowości uważają, że przy badaniach należy brać pod uwagę zarówno zewnętrzne, jak i wewnętrzne uwarunkowania ludzkiego zachowania.

${ }^{7}$ H. Gasiul, Psychologia osobowości. Nurty, teorie, koncepcje, Wyd. 2, Warszawa 2012, s. 58.

${ }^{8}$ D. Cervone, L.A. Pervin, Osobowość. Teoria i badania, s. 10.

9 Struktura osobowości to określenie „całościowej organizacji zachowania: uczuć, percepcji i pragnień charakterystycznych dla każdej jednostki” S. Siek, Struktura osobowości, Warszawa 1986, s. 26.

${ }^{10}$ Pomimo tego, że na wstępie niniejszej pracy został podana ogólna definicja osobowości, to wypada przytoczyć definicje, które skonstruowali Allport i Cattell, gdyż na 
badacze starali się opisać strukturę osobowości na podstawie cechowego jej ujęcia ${ }^{11} . Z$ codziennej obserwacji łatwo można dostrzec fakt opisywania ludzi poprzez przypisywanie im $\operatorname{cech}^{12}$. Potrafimy dostrzec czyjąś pracowitość bądź lenistwo, błyskotliwość i pomysłowość oraz niezaradność lub niechlujstwo. Mówiąc w ten sposób o ludziach, przypisujemy im cechy, czyli określenia typowe dla danej jednostki. Zatem cechy rozumie się jako dominanty (właściwości, predyspozycje) psychologiczne, które wykazują się stabilnością w czasie i sytuacjach przy równoczesnym uwzględnieniu kontekstu społecznego (to, że ktoś jest towarzyski nie oznacza, że będzie taki zawsze wobec np. materii nieożywionej. Chodzi zatem o zachowania osoby, które zazwyczaj w większości sytuacji są takie same, a nie o konkretne sytuacje). Jeśli daną osobą spostrzegamy jako sympatyczną czy szczerą, to posiadamy przekonanie, iż ta osobą będzie się charakteryzować tymi cechami także za miesiąc. W ten sposób cecha posiada właściwość stałości. Ponadto charakteryzuje się ona również odrębnością, która sprawia, że dany człowiek wyróżnia się wśród innych. Można zatem pokusić się o stwierdzenie, że cechy są najbardziej znaczącymi składowymi osobowości. To „stałe wzorce, według których ludzie czują, myślą i postępują"13. Dzięki cechom można z dużym prawdopodobieństwem określić jak dana osoba się zachowa, co pomyśli lub jak będzie się czuła w różnych

ich badaniach opiera się treść artykułu. Allport definiował osobowość jako: „dynamiczną organizację w jednostce tych systemów psychofizycznych, które determinują jej specyficzne przystosowanie się do jej środowiska”. Natomiast Cattell twierdził, że „osobowość jest tym, co pozwala przewidzieć, co dana osoba zrobi w danej sytuacji”. C.S. Hall, G. Lindzey, J.B. Campbell, Teorie osobowości, Warszawa 2013, s. 279, 319.

Osobowością w ujęciu cechowym zajmował się również Hans J. Eysenck, jednakże przedmiot jego zainteresowań nie obejmował określenia na czym polega osobowa dojrzałość. W związku z tym nie została w niniejszej publikacji zaprezentowana jego koncepcja. Zob. S. Tokarski, Obraz Boga a dojrzałość osobowa, Warszawa 2011, s. 214-215.

${ }^{11}$ Psychologia osobowości w perspektywie cechowej diametralnie różni się od psychoanalitycznej tym, że wykorzystuje obiektywne i naukowe pomiary, których pozbawione są dzieła Freuda. Freud opierał się przede wszystkim na studium przypadków, czyli na subiektywnych interpretacjach nie wykorzystując pomiaru naukowego. Teoria czynnikowa bazuje na badaniach i przeprowadzanych pomiarach.

12 Cecha jest „strukturą psychiczną, czymś wywnioskowanym z obserwowanego zachowania w celu wyjaśniania regularności czy spójności tego zachowania”. C.S. Hall, G. Lindzey, J.B. Campbell, Teorie osobowości, s. 320.

${ }^{13}$ D. Cervone, L.A. Pervin, Osobowość. Teoria i badania, s. 278. 
sytuacjach. Są to pewnego rodzaju tendencje, które przejawia jednostka i jeśli odznaczają się dużym nasileniem, stanowią wówczas podstawowe części składowe osobowości. Tak więc istnieje ścisłe powiązanie pomiędzy ludzkim zachowaniem, a posiadanymi cechami ${ }^{14}$.

Allport wśród cech wyróżniał dominujące, główne i dyspozycje wtórne. Cechy z pierwszej grupy są tak wyraźne, iż determinują ludzkie zachowanie, stając się źródłem jego działań. Przeważnie ludzie posiadają mało cech dominujących, a nierzadko zdarza się, że ich w ogóle nie mają. Cechy główne według Allporta, takie jak uczciwość, asertywność czy uprzejmość posiadają znaczący wpływ na zachowanie osoby, ale mają ograniczony zakres sytuacyjny w porównaniu do cech dominujących. Natomiast dyspozycje wtórne jest najtrudniej dostrzec i nie wykazują wewnętrznej spójności. Przytoczony schemat wskazuje na możliwość podziału cech ze względu na stopień ważności i ogólności ${ }^{15}$.

Cattell natomiast dzielił cechy na powierzchniowe i źródłowe. Te pierwsze są najbardziej widoczne - łatwo je można dostrzec na podstawie obserwacji zachowań danej osoby. Chcąc zidentyfikować pewne struktury psychiczne stanowiące podstawę obserwowanych zachowań (tendencji behawioralnych), na podstawie zastosowanej analizy czynnikowej, wyodrębnił 16 cech źródłowych ${ }^{16}$. Są nimi: cyklotymia-schioztymia (czynnik A),

${ }^{14}$ Jeśli człowiek jest opanowany i spokojny, to w ujęciu cechowym posiada cechę łagodności. W podejściu psychoanalitycznym wcale tak być nie musi - osoba może być tak bardzo niespokojna, że tłumi w sobie niepokój twierdząc, że jest spokojna.

15 Zob. D. Cervone, L.A. Pervin, Osobowość. Teoria i badania, s. 286. Por. C.S. Hall, G. Lindzey, J.B. Campbell, Teorie osobowości, s. 283.

16 S. Siek, Osobowość a higiena psychiczna, Warszawa 1980, s. 104-113. Por. A.J. Nowak, Osobowość w ujęciu R.B. Cattella, „Studia Philosophiae Christianae”, 10 (1974) 2, 175. Można spotkać uwspółcześnione nazewnictwo: wylewny-powściągliwy, bardziej inteligentny-mniej inteligentny, zrównoważony-emocjonalny, dominujący-uległy, beztroski-poważny, sumienny-niesumienny, śmiały-płochliwy, delikatny-twardy, podejrzliwy-ufny, fantazyjny-praktyczny, wnikliwy-naiwny, bojaźliwy-pewny siebie, postępowy-konserwatywny, samodzielny-zależny, kontrolujący się-nieplanujący, napięty-spokojny. Zob. D. Cervone, L.A. Pervin, Osobowość. Teoria i badania, s. 294; C.S. Hall, G. Lindzey, J.B. Campbell, Teorie osobowości, s. 324-325.

Na podstawie tych cech został opracowany „Szesnastoczynnikowy Kwestionariusz Osobowości” Polska adaptacja kwestionariusza została dokonana przez M. Nowakowską. Zob. M. Nowakowska, Polska adaptacja 16-czynnikowego Kwestionariusza Osobowości R.B. Cattella”, „Psychologia Wychowawcza”, 13 (1970), s. 478-501. 
inteligencja-ociężałość umysłowa (czynnik B), siła ego-skłonność do zachowań neurotycznych (czynnik C), dominacja-submisja, uległość (czynnik E), ekspansywność-brak ekspansywności (czynnik F), siła superego-niskie superego, charakter niedojrzały (czynnik G), odporność psychiczna-brak odporności psychicznej (czynnik H), wrażliwość-szorstkość, brak subtelności (czynnik I), skłonność do reakcji paranoidalnych-wewnętrzne odprężenie (czynnik L), nieliczenie się z konwencjami-konwencjonalność (czynnik M), przenikliwość, racjonalizm-naiwność, prostota (czynnik N), poczucie winy, niepewność siebie-zaufanie do siebie (czynnik $\mathrm{O}$ ), radykalizm-konserwatyzm (czynnik $\mathrm{Q}_{1}$ ), samowystarczalność-uzależnienie się od innych (czynnik $\mathrm{Q}_{2}$ ), samokontrola, siła woli-gnuśność, niezadowolenie z siebie (czynnik $\mathrm{Q}_{3}$ ), wysokie napięcie potrzeb i popędów-niskie napięcie ergiczne (czynnik $\mathrm{Q}_{4}$ ). Wśród 16 cech źródłowych Cattell wyróżnił trzy kategorie: cechy zdolnościowe (odnoszą się do zdolności i umiejętności np. inteligencja), temperamentalne (odnoszą się do życia emocjonalnego np. powolność impulsywność w działaniu), dynamiczne (odnoszą się do dążeń i motywacji). Według badacza cechy zdolnościowe, temperamentalne oraz dynamiczne są najbardziej stabilnymi elementami osobowości człowieka. Cechy źródłowe według Cattella odpowiadają „za łączenie się poszczególnych cech i schematów reagowania w specyficzne grupy składające się na oba bieguny poszczególnych wymiarów"17 (np. łatwy w pożyciu, łatwo adoptujący się, serdeczny lub oporny, mało elastyczny, obojętny - to niektóre cechy z wymiaru/czynnika A cyklotymia-schizotymia).

Cattell nie pojmował osoby statycznie, czyli tak, jakby zachowywała się tak samo w każdej sytuacji. Według niego ludzkie zachowanie zależy nie tylko od posiadanych cech, ale również od stanów i ról. Przez stan rozumie nastrój, który posiada osoba w danym momencie np. niepokój, zmęczenie, pobudzenie. Przeżywany stan, którego doświadcza jednostka $\mathrm{w}$ danym momencie, ma taki sam wpływ na ludzkie zachowanie, jak posiadane cechy. Odnośnie ról Cattell był zdania, że niektóre zachowania są ściśle z nimi powiązane. $\mathrm{Z}$ własnego doświadczenia wiemy, że ze względu na pełnioną rolę nie przystoi nam jakieś zachowanie. Stąd też Cattell był zdania, że aby dokładnie opisać osoby w określonym czasie, należy dokonać pomiaru zarówno cech, jak stanów z uwzględnieniem pełnionych

17 S. Siek, Struktura osobowości, s. 53-54. 
ról. Cechy zapewniają stabilność w zachowaniu, niemniej aktualny stan (nastrój), w którym jest osoba oraz pełniona przez nią określona rola mogą mieć na dane zachowanie wpływ, zmieniając je.

\section{KRYTERIA DOJRZAŁEJ OSOBOWOŚCl}

Według Allporta dojrzała osobowość jest stanem docelowym rozwoju każdej osoby, który niestety nieczęsto jest przez nią osiągany. Wyznacznikiem zdrowej osobowości jest jej dojrzałość, na którą składają się następujące kryteria ${ }^{18}$ :

- poszerzanie zakresu rozumienia i interesowania się otoczeniem. $\mathrm{W}$ miarę dorastania poszerzają się zainteresowania jednostki - dziecko w początkowym stadium swego życia jest skupione przede wszystkim na relacjach $\mathrm{z}$ rodzicami, następnie obszar ten ulega rozszerzeniu na innych ludzi. Człowiek z dojrzałą osobowością interesuje się problemami innych ludzi, sprawami zawodowymi, moralnymi czy polityką. Poszerzają się kontakty międzyludzkie, zawierane są nowe znajomości, nawiązują więzi, osobiste doświadczenie życiowe ulega pogłębieniu. Także podejmowane są różne formy aktywności pozwalające na rozwój własnego „ja”, lecz rozumianego nie w sensie zaspokajania własnych potrzeb;

- życzliwość wobec innych ludzi, okazywanie ciepła w relacjach osobowych zarówno $\mathrm{w}$ relacjach $\mathrm{z}$ bliskimi, z którymi nawiązuje się intymne więzi poprzez akceptację, empatię, miłość, jak i z szerszym otoczeniem, co przejawia się w umiejętności rozumienia, współodczuwania emocji w sytuacjach egzystencjalnych. Ponadto dojrzała osobowość charakteryzuje się tolerancją wobec niedostatków i wad innych osób oraz brakiem zbytnio pochopnego reagowania i oceniania;

${ }^{18}$ Na podstawie S. Tokarski, Obraz Boga a dojrzałość osobowa, s. 202-204. Zob. też J. Zamorski, Dojrzałość psychologiczna. Uwarunkowania wychowawcze obrazu siebie, Lublin 2003, s. 61-62. 
- dojrzałość emocjonalna, która wiąże się z akceptacją samego siebie oraz odpornością na frustrację przejawiającą się np. w spokojnym przyjęciu sytuacji w wypadku, kiedy nie układa się ona według zamierzeń i pragnień danej osoby. Dzięki temu frustracja nie paraliżuje działania, a jej opanowanie pozwala kontynuację podjętych przedsięwzięć pomimo odczuwanego stresu czy niezadowolenia. Natomiast akceptacja siebie samego to nic innego, jak zdolność uznawania siebie w pełni, czyli swoich słabości, niedoskonałości, niedomagań przy równoczesnym wypełnianiu posiadanych potencjałów i zdolności. Mieści się też tu akceptacja emocjonalności, czyli jej rozumienie i afirmacja jako coś, co przynależy do ludzkiego istnienia i własnego „ja”. Przejawia się ona w opanowywaniu, a nie odrzucaniu niepożądanych emocji i przyczynia się do rozwoju szacunku wobec samego siebie;

- realistyczne spostrzeganie (percepcja), czyli pełny kontakt z rzeczywistością bez jej zniekształcania przez pryzmat własnych pragnień, potrzeb czy zamierzeń. $\mathrm{W}$ utrzymywaniu realistycznego spostrzegania pomaga obiektywizm, który można uzyskać poprzez porównywanie własnych ocen $\mathrm{z}$ ocenami i percepcją innych ludzi. Dokonuje się wówczas właściwe rozróżnienie tego, co się widzi i rozumie, od tego czego się chce, pragnie i przed czym odczuwa się lęk;

- zarządzanie (kierowanie) nawykami i kompetencjami, które się posiada, rozwija lub nabywa nowe. Istotne jest to zwłaszcza, gdy osoba przeżywa trudne sytuacje, których rozwiązanie wymaga posiadania zdolności i kompetencji, których jednostka nie ma. Ważne jest, by wówczas skutecznie zarządzała i wykorzystała kompetencje, które posiada w celu przetrwania sytuacji trudnej. Wywołuje to podjęcie różnych aktywności, a także daje satysfakcję i zwiększa poczucie wartości;

- znajomość samego siebie, która przejawia się w trzech płaszczyznach: w tym, co osoba potrafi, czego nie potrafi i co powinna robić. Posiadana wiedza o samym sobie i jej stabilność czyli samoświadomość to istotne wyznaczniki dojrzałości. Stabilizacja wiąże się z pełnionymi rolami (np. żony, męża, rodzica, pracownika) oraz nabytym i powiększającym się doświadcze- 
niem życiowym. Ważna jest tu również otwartość na opinie środowiska, czyli innych ludzi, co staje się źródłem lepszego poznania samego siebie i nawiązanych relacji $\mathrm{z}$ innymi osobami;

- posiadanie jednoczącej filozofii życia (nabytej lub osobiście stworzonej), która przejawia się w dawaniu sobie odpowiedzi na fundamentalne pytania dotyczące celowości swojej egzystencji. Wiąże się to również z posiadaniem własnych planów (czasem długoterminowych), wyznawaniem wartości, ideałów, motywacji i poszukiwaniu sensu własnego życia. Z tym wymiarem łączy się przestrzeń religijna i wyznawanie wiary.

Można powiedzieć, że Allport wyodrębnił trzy obszary składające się na dojrzałą osobowość. Są nimi: posiadanie właściwie rozwiniętego i rozbudowanego obrazu samego siebie, posiadanie umiejętności wglądu w siebie (znajomość siebie i kształtowanie obiektywnych postaw wobec siebie), posiadanie spójnego światopoglądu ${ }^{19}$. Te trzy obszary realizują się w konkretnych zachowaniach i postawach osoby. Pierwszy przejawia się w ograniczaniu skłonności egoistycznych, liczeniu się z dobrem drugiej osoby, posiadaniu i rozwijaniu zainteresowań (indywidualnych, jak i w powiązaniu z innymi ludźmi), posiadaniu przyjaciół i kontaktów społecznych, darzenie innych sympatią. Mieści się w tym też posiadanie ideału samego siebie (który się stara zrealizować) i wypełnianiu wzorców moralnych, przejawianych $\mathrm{w}$ postępowaniu akceptowanym przez społeczeństwo. Drugi obszar wraz z rozwojem wglądu w siebie realizuje się $\mathrm{w}$ dokonywaniu porównania własnego obrazu siebie $\mathrm{z}$ obrazem, jaki mają inni. To również brak rzutowania własnych wad na innych ludzi, a także nieprzypisywanie im cech i reakcji, których się w sobie nie aprobuje. Osoby z wglądem w siebie odznaczają się poczuciem humoru z dostrzeganiem u siebie śmiesznych cech. Osoby niedojrzałe nie posiadają takiej umiejętności - zachowują się jak dzieci, czyli nie potrafią śmiać się $\mathrm{z}$ siebie, ale naigrawają się z innych. Trzeci obszar i posiadanie własnego światopoglądu Allport rozumiał jako wypracowanie przez jednostkę

19 Zob. G.W. Allport, Personalisty a Psychological Interpretation, Londyn 1949, s. $217-231$. 
własnej hierarchii wartości, która spełnia funkcję integrującą i scalającą funkcjonowanie osobowości ${ }^{20}$.

Według Allporta dojrzała osobowość przejawia się w indywidualności człowieka, co pozwala na formułowanie przez niego sądów i podejmowania suwerennych decyzji. Dzięki temu osoba żyje w harmonii z sobą i otoczeniem.

Odnośnie do Cattella - drugiego po Allporcie - badacza osobowości, należy podkreślić, że trudno znaleźć w jego publikacjach pełną definicję dojrzałej osobowości. Niemniej w oparciu o jego koncepcję struktury osobowości można stworzyć zarys modelu dojrzałej i dobrze przystosowanej osobowości. Dojrzały człowiek charakteryzuje się następującymi schematami reagowania:

- „czynnik A: jest łatwy w pożyciu, serdeczny, otwarty, łatwo adaptujący się, ufny, nastawiony na współpracę, mający poczucie humoru, dojrzały emocjonalnie, umiejący wyrazić swoje uczucia, posiadający wgląd w siebie, umiejący się cieszyć przyjemnościami życiowymi,

- czynnik B: inteligentny, wytrwały, sumienny, obstający przy swoim, systematyczny, dokładny, mający szerokie zainteresowania, prawdomówny, kierujący się zdrowym rozsądkiem,

- czynnik C: stabilny uczuciowo, stały w postępowaniu, posiadający poczucie życiowego realizmu, kontrolujący swoje zachowania, cierpliwy, obstający przy swoim, lojalny, liczący się z regułami obowiązującymi w danej kulturze,

- czynnik E: pewny siebie, dążący do jak najlepszego wykonania tego, co robi,

- czynnik F: wesoły, towarzyski, z dobrym kontaktem, energiczny, spokojny, pomysłowy, umiejący szybko pracować,

- czynnik G: zdeterminowany do działania, odznaczający się poczuciem odpowiedzialności, liczący się z ludźmi,

- czynnik H: śmiały, spontaniczny, lubiący nawiązywać kontakty z ludźmi, naturalny w zachowaniu,

20 Zob. S. Siek, Osobowość a higiena psychiczna, s. 40; J. Bazylak, Psychoterapia i wychowanie religijne, Warszawa 1991, s. 92-93. 
- czynnik I: wybredny pod względem estetycznym, posiadający wrażliwą wyobraźnię, wewnętrznie niezależny,

- czynnik L: rozumiejący i akceptujący innych,

- czynnik M: liczący się z konwencjami,

- czynnik N: umiejący się znaleźć w towarzystwie, posiadający umiejętność wglądu w siebie i innych,,

- czynnik $Q_{2}$ : samowystarczalny,

- czynnik $\mathrm{Q}_{3}$ : o silnej woli, trwałych zainteresowaniach, wytrwały, odporny w działaniu, w którym spotykają go przeszkody, lubiący atakować i rozwiązywać trudne problemy,

- czynnik $\mathrm{Q}_{4}$ : rozluźniony, mający zaspokojone silne własne potrzeby i popędy"21.

${ }^{21}$ S. Siek, Osobowość a higiena psychiczna, s. 114-115.

Można także wyróżnić cechy niedojrzałej i źle przystosowanej osobowości według koncepcji Cattella. W modelu tym osoba charakteryzuje się następującymi schematami reagowania:

"- czynnik A: oporny, kłótliwy, sztywny, chłodny, obojętny, skryty, podejrzliwy, wrogo nastawiony do ludzi, liczący się z własną korzyścią, oschły, niewrażliwy, traktujący ludzi w sposób bezosobowy, zazdrosny, ujawniający skłonności homoseksualne,

- czynnik B: nieinteligentny, prostacki, łatwo porzucający to, co robi,

- czynnik C: ujawnianiem reakcji neurotycznych, hipochondrią, zmiennością, pobudliwością, niecierpliwością, domaganiem się specjalnego uznania i uwagi, zmiennym i wykrętnym postępowaniem,

- czynnik E: samochwał, agresywny, działający siłą, niewrażliwy na społeczną dezaprobatę, a także nadmiernie ugrzeczniony, miękki, potulny,

- czynnik F: depresyjny, pesymistyczny, izolujący się i unikający działania, podejrzliwy,

- czynnik G: lekkomyślny, lekceważący społeczne zobowiązania, ujawniający brak skrupułów, zmienny, litujący się nad sobą,

- czynnik H: twardy, zahamowany, skrupulatny, niemający do siebie zaufania, ujawniający lęk przed życiem,

- czynnik I: wymagający, niecierpliwy,

- czynnik L: zazdrosny, unikający kontaktów z ludźmi,

- czynnik M: nieliczący się z konwencjami, ekscentryczny, ujawniający niekiedy reakcje histeryczne, dążący do zwracania na siebie uwagi,

- czynnik N: naiwny, niemający wglądu w siebie, niezręczny w kontaktach z ludźmi,

- czynnik O: zamartwiający się, przeżywający poczucie osamotnienia, łatwo zniechęcający się, 
Jak można zauważyć z powyższych rozważań, zdefiniowanie osobowości nie jest łatwym zadaniem. Psychologia nie określa tej rzeczywistość w sposób jednoznaczny, ale opisuje ją nakreślając różne aspekty w zależności od podejścia nurtu psychologicznego. Na potrzeby niniejszego artykułu charakterystyka osobowości została zaprezentowana ujęciu humanistycznym i cechowym, którego reprezentantami są między innymi Gordon W. Allport i Raymond B. Cattell. Zostały również podane predykatory dojrzałej, dobrze przystosowanej osobowości. Ma to szczególne znaczenie, bowiem nie jest łatwo w literaturze psychologicznej znaleźć precyzyjnie opisane jej wyznaczniki. Opracowanie to przyjmuje zatem rolę punktu odniesienie dla kolejnych rozważań dotyczących znaczenia dojrzałej osobowości u osób przygotowujących się do małżeństwa oraz do przedstawienia wpływu i konsekwencji braku jej posiadania przez małżonków na konflikty, jakie mogą się pojawić w ich relacjach.

Streszczenie. Przyglądając się kondycji współczesnych małżeństw, można zauważyć przez ostatnie dekady wzrost ilości rozwodów. Jedną z przyczyn jest niedojrzała osobowość małżonka (małżonków). Niniejsze opracowanie stara się przybliżyć i opisać czym jest dojrzała osobowość i jakie są jej kryteria. Dokonuje się tego na podstawie psychologii humanistycznej, której przedstawicielami są G.W. Allport i R.B. Cattell, wykorzystując cechowe ujęcie osobowości. Dzięki wyszczególnionym kryteriom można zrozumieć, jakimi cechami charakteryzuje się człowiek o dojrzałej osobowości. Jej wyznaczniki to między innymi: realistyczne spostrzeganie rzeczywistości, umiejętność rozwiązywania problemów, nawiązywanie i utrzymywanie bliskich relacji z ludźmi, posiadanie dojrzałej emocjonalności, samorealizacja i samowychowanie, posiadanie zwartego światopoglądu, hierarchii wartości i przekonań religijnych. Opracowanie to przyjmuje rolę punktu odniesienie dla kolejnych rozważań w kontekście małżeństwa wskazując na przełożenie braku posiadania dojrzałej osobowości przez małżonków na konflikty, jakie mogą się pojawiać między nimi.

Słowa klucze: małżeństwo; relacje; osobowość; dojrzałość; dojrzała osobowość.

Summary. The Concept of the Mature Personality and its Indicators - A Prologue to Reflections in the Context of Marriage Preparation. Looking at the condition of modern marriages, a growing number of divorces has been observed over the last

- czynnik $\mathrm{Q}_{1}, \mathrm{Q}_{2}, \mathrm{Q}_{3}, \mathrm{Q}_{4}$ : skrajny konserwatyzm, uzależniający się od innych, gnuśny i niezadowolony z siebie, napięty o sfrustrowanych potrzebach i popędach". S. Siek, Osobowość a higiena psychiczna, s. 116-117. 
decades. One of the reasons is the immature personality of spouse (spouses). The aim of the article is to present and analyse the mature personality and its criteria relying on humanistic psychology and applying trait theory, whose representatives are G. W. Allport and R. B Cattell. Thanks to these criteria, it is possible to understand the characteristic traits of mature personality. The indicators are, among others, realistic perception of reality, problem solving skills, creating and maintaining close relationships with people, possessing mature emotionality, self-actualization, self-education, coherent worldview, hierarchy of values and religious convictions. The article is a reference point for further reflections on marriage indicating that the lack of mature personality of spouses may result in conflicts between them.

Keywords: marriage; relationship; personality; maturity; mature personality.

\section{BIBLIOGRAFIA}

Allport G.W., Personalisty a Psychological Interpretation, Londyn 1949.

Bazylak J., Psychoterapia $i$ wychowanie religijne, Warszawa 1991.

Cervone D., Pervin L.A., Osobowość. Teoria i badania, Wyd. 10, Kraków 2011.

Dobkowska D., Zdolność psychologiczna do małżeństwa, w: Osobowość kandydata do małżeństwa, R. Sztychmiler (red.), Olsztyn 1999, s. 71-79.

Gasiul H., Psychologia osobowości. Nurty, teorie, koncepcje, Wyd. 2, Warszawa 2012.

Główny Urząd Statystyczny, Rocznik Demograficzny, Warszawa 2016.

Hall C.S., Lindzey G., Campbell J.B., Teorie osobowości, Warszawa 2013.

Namysłowska I., Terapia rodzin, Warszawa 1997.

Nowak A.J., Osobowość w ujęciu R.B. Cattella, „Studia Philosophiae Christianae”, 10 (1974) 2, s. 167-182.

Nowakowska M., Polska adaptacja 16-czynnikowego Kwestionariusza Osobowości R.B. Cattella”, „Psychologia Wychowawcza”, 13 (1970), s. 478-501.

Siek S., Osobowość a higiena psychiczna, Warszawa 1980.

Siek S., Struktura osobowości, Warszawa 1986.

Sztychmiler R. (red.), Osobowość kandydata do małżeństwa, Olsztyn 1999.

Sztychmiler R., Przygotowanie do małżeństwa w aspekcie osobowości kandydata ,w: Osobowość kandydata do małżeństwa, R. Sztychmiler (red.), Olsztyn 1999, s. 81-105.

Tokarszki S., Obraz Boga a dojrzałość osobowa, Warszawa 2011.

Zamorski J., Dojrzałość psychologiczna. Uwarunkowania wychowawcze obrazu siebie, Lublin 2003. 
